\title{
NATURAL AREAS AND SITES OF CANADIAN SIGNIFICANCE IN SASKATCHEWAN.
}

CLAUDE MONDOR, Head, Area Identification Branch, National Parks Branch, 10 Wellington Street, Ottawa, Ontario. K1A $1 G 2$

During the past decade Parks Canada has conducted studies across Canada to identify natural areas that are of national importance. Although some of these areas have since been designated as national parks, provincial parks or equivalent reserves, and others may be protected in the future, many will remain without adequate conservation measures in place. However, by informing the public of the importance of these areas, as well as those that are responsible for their management, it is hoped that proper stewardship of the areas' resources will continue.

A number of nationally significant areas and sites have been identified in Saskatchewan during the conduct of Parks Canada's studies. This article summarizes these studies, the two types of nationally significant natural properties that Parks Canada is concerned with and presents a brief description of those areas in the province that have been identified to date. It is important for the reader to note that this list is incomplete and that no account has been taken of the areas' protective status.

\section{Identifying Canada's Natural Heritage}

The National Parks Branch, which is the agency in Parks Canada responsible for the establishment of new riational parks and Canadian landmarks, has developed two methods for identifying natural properties of Canadian significance. These two methods are: (1) natural region studies; and, (2) natural theme studies.

Before the natural region study method is described, however, it is appropriate to outline the basis for planning the system of national parks in Canada. Since one of the fundamental objectives of national parks is to protect outstanding examples of Canada's natural heritage, it follows that they should be identified, studied and understood in the context of the country's natural history. Consequently, Parks Canada adopted the "natural region concept" for planning its network of national parks in the early 1970's.

This approach entailed dividing Canada into appropriate geographical units for conservation purposes. The thirty-nine natural regions which resulted from this exercise are described in the National Parks System Planning Manual and are illustrated on Map 1. Each natural region has a distinctive character which is determined by its unique combination of natural themes (climate, geology, landforms, vegetation and wildlife). Parks Canada's long-term goal is to ensure the protection of an outstanding example of each natural region in the national park system. Parts of five natural regions are found in Saskatchewan: the Southern Boreal Plains (Region 12); the Prairie Grasslands (Region 13); the Manitoba Lowlands (Region 14); the Northwestern Boreal Uplands (Region 17); and, the Central Boreal Uplands (Region 18).

Natural region studies, or "regional analysis" as they are also referred to, involve three steps. The first step is to determine the unique combination of climate, geology, landforms, plant and animal life that gives the natural region its distinctive individuality. The second step is to identify areas throughout the region that are in a relatively natural state and which include the diversity of the region's natural features. 


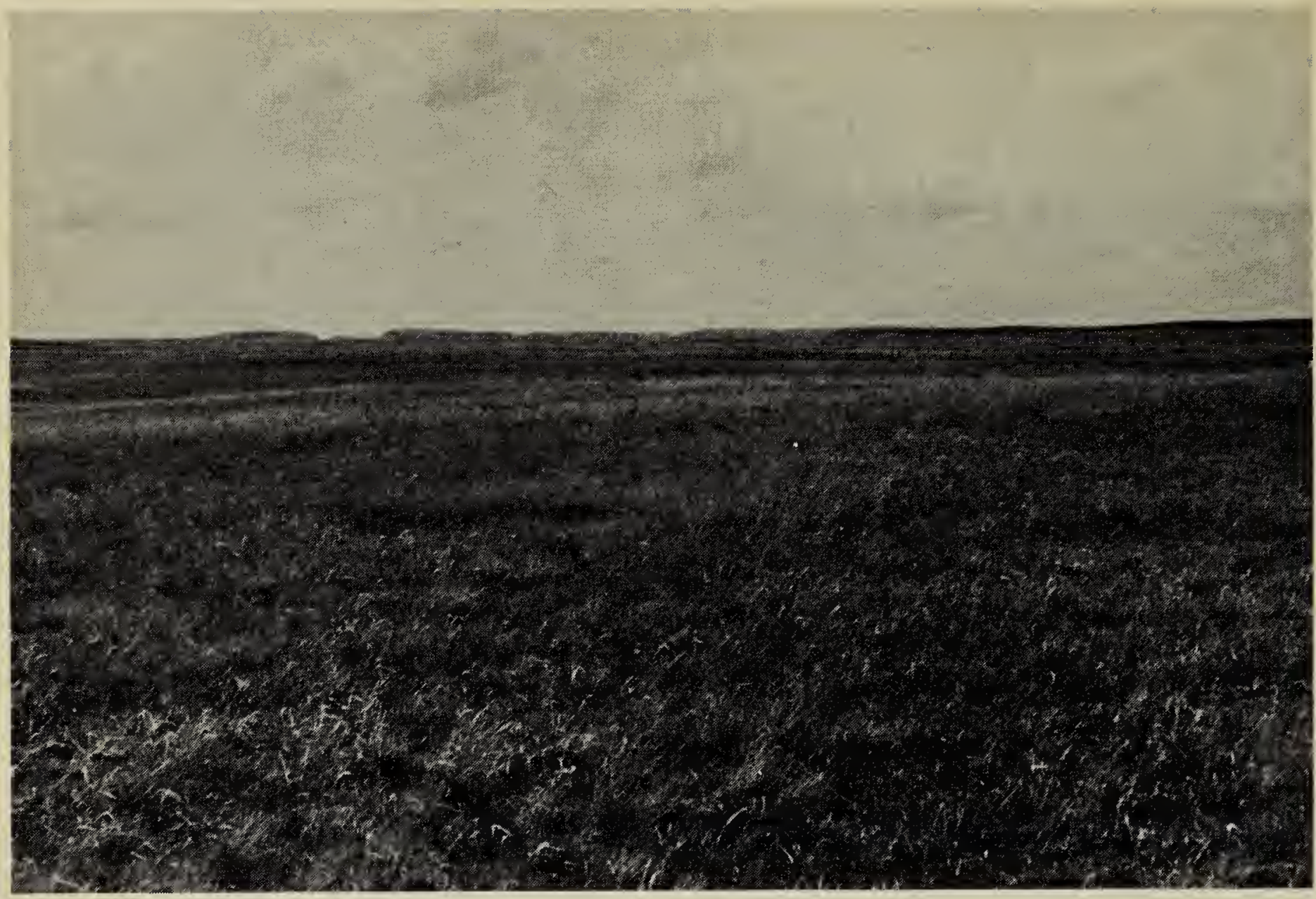

Grasslands Park area

G.W. Seib

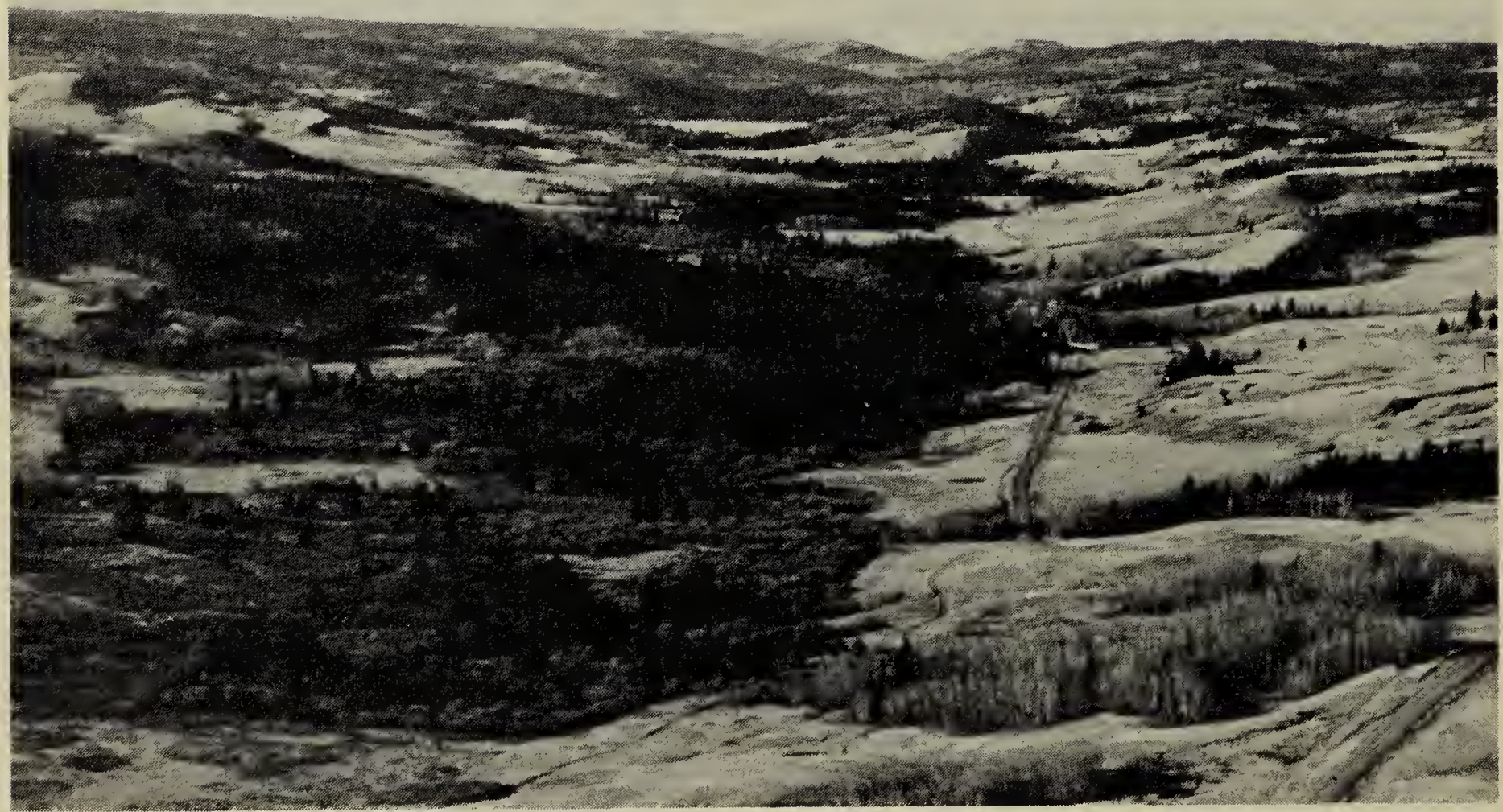

Battle Creek, Cypress Hills

E. McGregor 
And finally, each of the areas identified in the previous step are then ranked in terms of the extent to which they are representative of the natural region under study. The most representative of these areas are referred to as "natural areas of Canadian significance", or by the acronym "NACS". Potential national parks are selected from among this group of natural areas according to the criteria for new national parks listed in the Parks Canada Policy.

Natural Theme Studes, on the other hand, are concerned with identifying the occurrence of a specific natural feature or phenomena throughout the country and assessing whether each site is of local, provincial or national significance according to a preconceived rating scheme. Sites of national importance are those which include features that are either rare (occur infrequently or are very few in Canada), unique (the only known example in Canada), or exceptional (considered by the scientific community as an outstanding or "classic" example of the natural feature under study). These properties are termed "natural sites of Canadian significance", or "NSCS". Natural sites of Canadian significance will be eligible for designation under the Canadian Landmarks program when it is approved by the federal, provincial and territorial governments.

\section{NACS in Saskatchewan}

Natural region studies have been conducted of all the natural regions that cover Saskatchewan with the exception of Natural Region 12 - the Southern Boreal Plains. Only a very general assessment of the degree to which the three existing national parks - Riding Mountain, Prince Albert and Elk Island - are representative of the Southern Boreal Plains has been conducted to date.

These studies have identified three areas that satisfy the above description of a natural area of Canadian significance: (1) the Churchill River; (2) Prince Albert National Park; and (3) the Val Marie - Killdeer area. The location of these areas is plotted on Map 2 and a short description of each follows.
Churchill River - The chain of interconnected lakes which are collectively called the "Churchill River" has been a place of unique value and inspiration for the Woodland Cree Indians during historic times, the voyageur and explorers of the Fur Trade and, more recently, for those that have canoed it.

Here, one can experience the elements that are typical of the "Canadian Shield", as the Central Boreal Uplands (Region 18) is commonly called. It is a landscape of glacial scoured Precambrian bedrock; boreal forest stands of Black Spruce, White Spruce, Balsam Fir and Jack Pine interspersed with shallow swamps and muskeg; lakes interconnected in a disorderly fashion by fast flowing streams; Moose, Woodland Caribou, Beaver, bear, Lynx, wolves, pickerel, mosquitoes and hoardes of blackflies.

The Churchill is considered by many as "...one of the best canoe rivers" in Canada, altered in a few places but essentially unchanged throughouts its length from Ile-a-la-Crosse to Frog Portage.

Prince Albert National Park - Prince Albert National Park is an outstanding example of the Southern Boreal Plains (Region 14), a region which is characterized by elements that are borrowed from the Prairie Grasslands to the south and the Canadian Shield to the north.

The Park's wildlife, for example, includes such prairie species as ground squirrels, Badger and Coyote, in addition to Moose, wolf, Lynx, caribou and Osprey that inhabit the northerly Shield country. It also includes one of Canada's largest colonies of the increasingly rare white pelican. The Park's vegetation also illustrates the region's transitional nature varying from aspen forest along its southern boundary, with an occasional patch of fescue grassland, to boreal forest in the northern limits. 


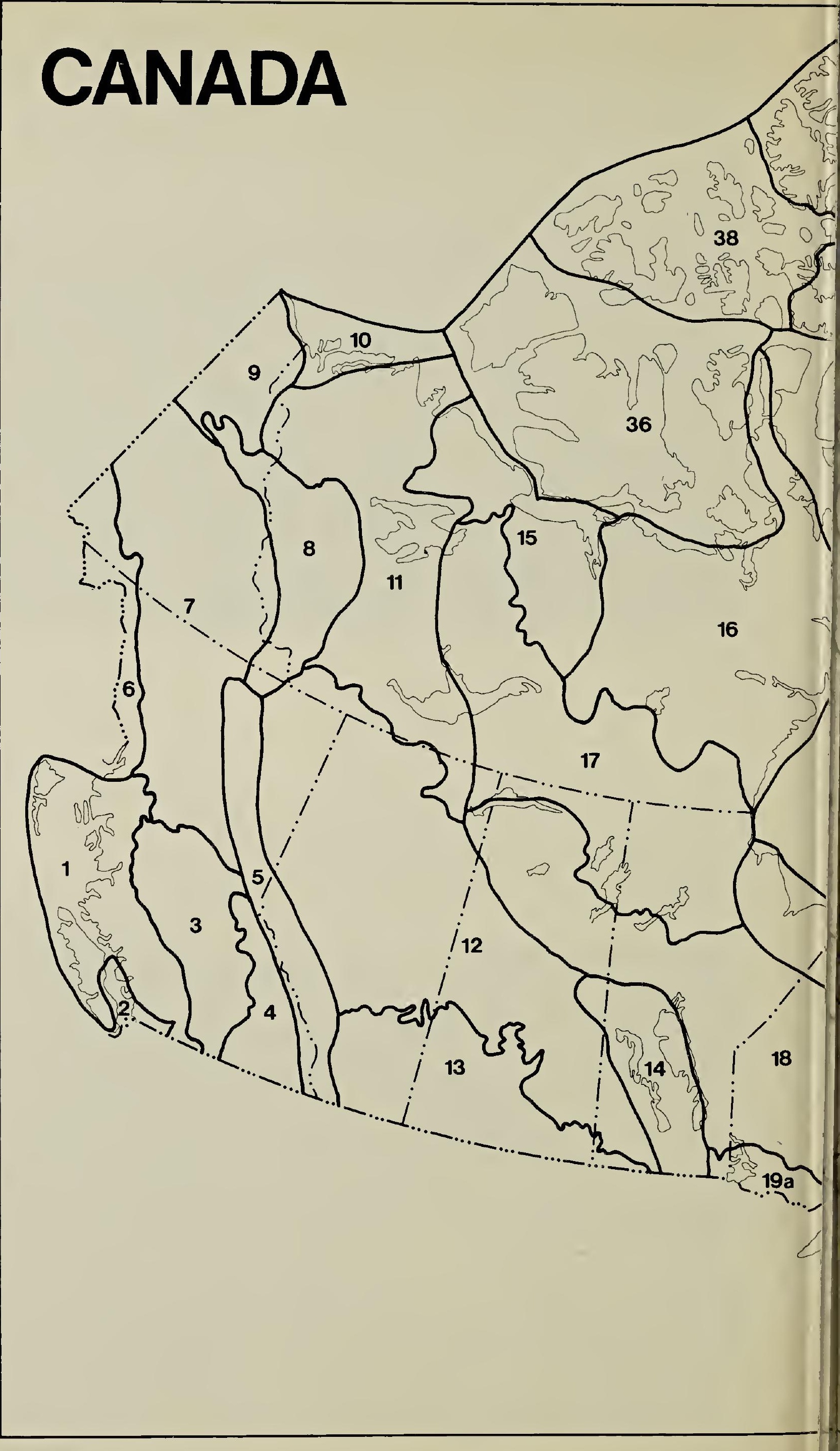




\section{NATIONAL PARK Map1 NATURAL REGIONS}

\section{WESTERN MOUNTAINS}

1. Pacific Coast Mountans 2. Strall of Georgia Lowlands 3. Interior Dry Plateau 4. Columbia Mountains 5. Rocky Mountains

. Northern Coast Mountains

. Northern Interior Plateaux and

Mountains

8. Mackenzie Mountains

9. Northern Yukon Region
INTERIOR PLAINS

10. Mackenzie Delta

Bareal Plans and Plateaux 3. Prarre Grasslands

14 Manitoba Lowlands

\section{CANADIAN SHIELD}

15. Tundra Hills

16. Central Tundra Aegon

17. Northwestern Boreal Uplands

8. Central Boreal Uplanos

19. (a) West Greal Lakes - St.

Lawrence Precambrian Region

Lawrence Precambrian Region

(c) East Great Lakes - St Lawrence

Precambrian Region

20. Laurentian Boreal Highlands

21. East Coast Boreal Region

22. Boreal Lake Plateau

23. Whale Piver Region

24. Northern Labrador Mountains

25. Ungava Tundra Plateau

26. Northern Davis Region
MUDSON BAY LOWLANOS

27. Hudson-James Lowlands

28. Southampton Plain

\section{ST. LAWRENCE LOWLANDS}

29 (a) West St. Lawrence Lowland (b) Central St. Lawrence Lowlan (c) East St. Lawrence Lowland

APPALACMIAN

30. Notre Dame - Megantic Mountains

31. Martime Acadian Highlands

32. Martime Plain

33. Atlantic Coast Uplands

34. Western Newfoundland Island

Highlands

35. Eastern Newtoundland Island Allantic Region

\section{ARCTIC LOWLANDS}

36. Western Arctic Lowlands 37. Eastern Arctic Lowlands

MIGH ARCTIC ISLANDS

38. Western High Arclic Region

38. Western High Arclic Region
39. Eastern High Arctic Glacier Region

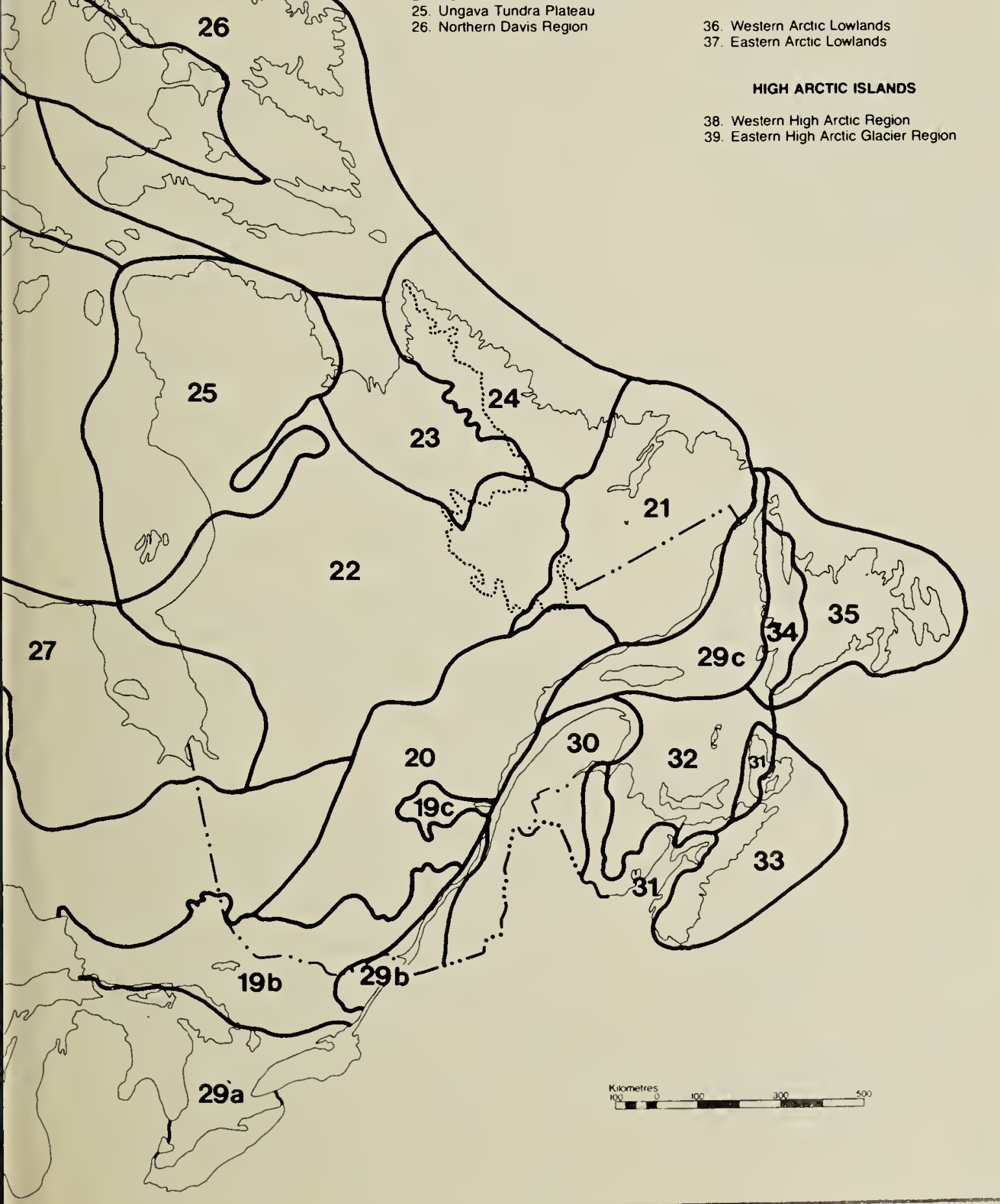


It was on the shore of Ajawaan Lake, located in the northern half of the Park, that Grey Owl, the colorful, controversial naturalist, author and orator spent many years.

Val Marie-Killdeer - This natural area of Canadian significance is one of the latest additions to the national park system, thanks to 20 years of efforts of the Saskatchewan Natural History Society to have a sizeable example of natural grassland in Canada protected.

In addition to the mixed prairie vegetation there exists a nearly complete sample of prairie fauna. Species ranging from the more common antelope and Richardson's Ground Squirrel or "gopher", to the rare and endangered Prairie Falcon, Ferruginous Hawk and Sage Grouse can be observed here. The Black-tailed Prairie Dog also resides within the proposed boundaries of this newly created park, the only place in Canada where this rodent occurs in its natural habitat.

The bizarre shaped landforms of the Killdeer Badlands, which comprise the eastern component of Grasslands $\mathrm{Na}$ tional Park, are not only of scenic interest to visitors, but are also a natural monument in the growth of the paleontological sciences in Canada. It was here where Sir George Mercier Dawson made the first recorded discovery of dinosaur remains while serving as geologist and naturalist to Her Majesty's North American Boundary Commission in 1874 .

\section{NSCS in Saskatchewan}

As the Canadian landmarks program is not yet operational only a few natural theme studies have been undertaken by Parks Canada over the past decade. The five natural sites of Canadian significance that have been identified in Saskatchewan as a result of these studies should also be considered as "preliminary" in the sense that criteria for the selection of this category of nationally significant property have not been finalized with the provincial and territorial governments. It is also important for the reader to take note that no comprehensive provincial inventory of sites that encompass a natural feature or phenomenon which is unique or rare in Canada or the world has been completed yet. Consequently, many more sites await discovery.

The natural sites of Canadian significance identified to date in Saskatchewan include: (1) the Athabasca Sand Dunes, (2) the Qu'Appelle Valley, (3) the Matador Site, (4) the Great Sand Hills, and (5) the Cypress Hills. Their approximate location is shown on Map 2 and a summary statement of their significant attributes are listed below.

Athabasca Sand Dunes - The Athabasca Sand Dunes, which extend from Ennuyeuse Creek to the MacFarlane River on the south side of Lake Athabasca in northwestern Saskatchewan, are the largest, single, uninterrupted active sand dune occurrence in Canada. The active dune system consists of complexes of sand dune ranging from ridges up to 35 $\mathrm{m}$ high not stabilized by vegetation to low dunes thinly covered by grasses and shrubs. In places sand dunes move across partially stablizied gravel pavements and exposed water tables or they form unstable sheets of loose sand.

This site is also recognized by botanists as an important centre of endemic plant species in Canada where a number of unique taxa have evolved in post-glacial times.

'Qu'Appelle Valley Spillway - The Qu'Appelle Spillway is the longest, widest, and deepest of glacial spillways in the Prairie Provinces and Canada. The Qu'Appelle was formed approximately 14,000 years ago as overflow from glacial lake Regina and meltwater from the retreating ice sheet carved a valley to a depth of 180 $\mathrm{m}$ and with a valley bottom up to 1.6 $\mathrm{km}$ wide. It is regarded by many geologists as a "classic" example of the meltwater channel and spillway landforms. 


\section{Map 2}

\section{SASKATCHEWAN}

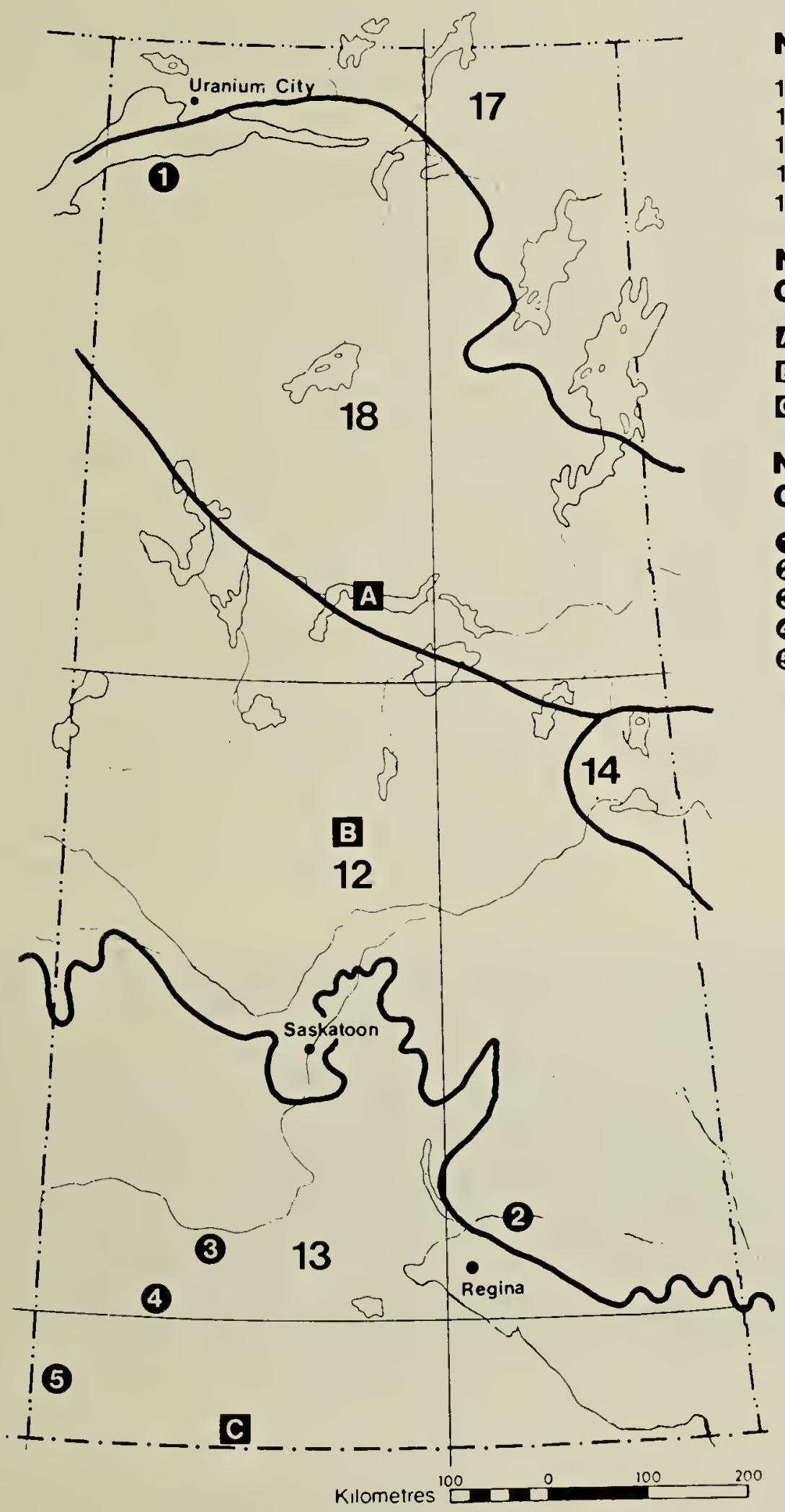

NATURAL REGIONS

12 Southern Boreal Plains

13 Prairie Grasslands

14 Manitoba Lowlands

17 Northwestern Boreal Uplands

18 Central Boreal Uplands

\section{NATURAL AREAS OF} CANADIAN SIGNIFICANCE

A Churchill River

B Prince Albert National Park

C Grasslands National Park

\section{NATURAL SITES OF} CANADIAN SIGNIFICANCE

(1) Athabasca Sand Dunes

2 Qu'Appelle Valley Spillway

(3) Matador

(4) Great Sand Hills

5 Cypress Hills 
Matador Grasslands - Most of this site is a grassland dominated by Northern Wheatgrass and June grass, one of the five major types of Mixed Prairie. This type of grassland formerly occupied areas of lacustrine clay soils, which because of their high moisture holding capacity, are considered very suitable for tillage. The Matador site is the largest remnant of this grassland type in Canada and is of international significance as a grassland research centre under the auspices of the International Biological Program.

Great Sand Hills - The Great Sand Hills, located approximately $70 \mathrm{~km}$ west of Swift Current are second in size to the Athabasca Dunes mentioned previously. The site includes a great variety of dune forms with blowouts and parabola dune forms being the most common. Other forms consist of circular, $\mathrm{V}$ - and U-shaped, shield, ridge-sided, fish-hook dunes and elongated sand ridges and border ridges. This sand dune occurrence is considered by some to be the most beautiful of all sand dunes sites known in Canada. It is also the best example of sandhill vegetation in the Prairie Grasslands.

Cypress Hills - To the Cree Indians the Cypress Hills were known as the "Muna-tuh-gow", which means the "Beautiful Highlands". This site encompasses a variety of geological, botanical and wildlife features that are rare or unique in Canada, and as such is of exceptional value and interest for the scientist and recreationist alike. It is, for example, one of the few areas in Canada that was unglaciated during the last continental glaciation. It is also a centre of rarity from a botanical perspective in that it represents an outlier containing numerous cordilleran, eastern arctic and northern boreal species. The faunal features of the Cypress Hills are similarly diverse and include an endemic snail and the rare and endangered Trumpeter Swan.

\section{Concluding Remarks}

In this article, I have presented a thumbnail sketch of how Parks Canada identifies natural areas and sites of Canadian significance and listed those areas within Saskatchewan which have been identified to date. Because the inventory is incomplete, readers are encouraged to submit any sites which, in their opinion, appear to satisfy the criteria for a natural area or natural site of Canadian significance. Suggestions should clearly identify the site's location, why that area is nationally important, and its current protective status. All suggestions should be forwarded to the following address: Chief, National Parks System Division, National Parks Branch, 10 Wellington Street, Ottawa, Ontario. K1A $1 G 2$

As the management of these properties is a provincial responsibility, a copy of the suggestions(s) should also be forwarded to the attention of Director, Parks Branch, Department of Tourism and Renewable Resources, Legislative Building, Regina, Saskatchewan. S4S 0B3. 